\title{
Mobile Nuclear-Hydrogen Synergy in NATO Operations
}

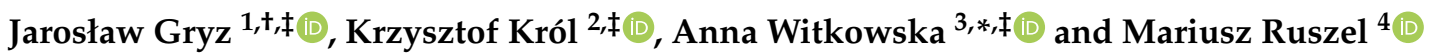 \\ 1 Faculty of National Security, War Studies University, Al. Gen. Chruściela “Montera”, 00-910 Warsaw, Poland; \\ j.gryz@akademia.mil.pl \\ 2 National Centre for Nuclear Reseach Radioisotope Centre POLATOM, ul. Andrzeja Sołtana 7, \\ 05-400 Otwock, Poland; krzysztof.krol@polatom.pl \\ 3 Ignacy Lukasiewicz Institute for Energy Policy, Technological Incubator 4, Jasionka 954E, \\ 36-002 Jasionka, Poland \\ 4 Faculty of Economics, Rzeszów University of Technology, 35-959 Rzeszów, Poland; mruszel@prz.edu.pl \\ * Correspondence: awitkowska@instytutpe.pl \\ + Current address: Faculty of National Security, War Studies University, Al. Gen. Chruściela "Montera" 103, \\ 00-910 Warsaw, Poland. \\ $\ddagger \quad$ These authors contributed equally to this work.
}

check for updates

Citation: Gryz, J.; Król, K.;

Witkowska, A.; Ruszel, M. Mobile Nuclear-Hydrogen Synergy in NATO Operations. Energies 2021, 14, 7955. https://doi.org/10.3390/en14237955

Academic Editors: Guglielmo

Lomonaco, Adam Revesz

and Attilio Converti

Received: 25 August 2021

Accepted: 10 November 2021

Published: 28 November 2021

Publisher's Note: MDPI stays neutral with regard to jurisdictional claims in published maps and institutional affiliations.

Copyright: (c) 2021 by the authors. Licensee MDPI, Basel, Switzerland. This article is an open access article distributed under the terms and conditions of the Creative Commons Attribution (CC BY) license (https:// creativecommons.org/licenses/by/ $4.0 /)$.

\begin{abstract}
An uninterrupted chain of energy supplies is the core of every activity, without exception for the operations of the North Atlantic Treaty Organization. A robust and efficient energy supply is fundamental for the success of missions and a guarantee of soldier safety. However, organizing a battlefield energy supply chain is particularly challenging because the risks and threats are particularly high. Moreover, the energy supply chain is expected to be flexible according to mission needs and able to be moved quickly if necessary. In line with ongoing technological changes, the growing popularity of hydrogen is undeniable and has been noticed by NATO as well. Hydrogen is characterised by a much higher energy density per unit mass than other fuels, which means that hydrogen fuel can increase the range of military vehicles. Consequently, hydrogen could eliminate the need for risky refuelling stops during missions as well as the number of fatalities associated with fuel delivery in combat areas. Our research shows that a promising prospect lies in the mobile technologies based on hydrogen in combination with use of the nuclear microreactors. Nuclear microreactors are small enough to be easily transported to their destinations on heavy trucks. Depending on the design, nuclear microreactors can produce 1-20 MW of thermal energy that could be used directly as heat or converted to electric power or for non-electric applications such as hydrogen fuel production. The aim of the article is to identify a model of nuclear-hydrogen synergy for use in NATO operations. We identify opportunities and threats related to mobile energy generation with nuclear-hydrogen synergy in NATO operations. The research presented in this paper identifies the best method of producing hydrogen using a nuclear microreactor. A popular and environmentally "clean" solution is electrolysis due to the simplicity of the process. However, this is less efficient than chemical processes based on, for example, the sulphur-iodine cycle. The results of the research presented in this paper show which of the methods and which cycle is the most attractive for the production of hydrogen with the use of mini-reactors. The verification criteria include: the efficiency of the process, its complexity and the residues generated as a result of the process (waste)—all taking into account usage for military purposes.
\end{abstract}

Keywords: nuclear synergy; hydrogen industry; nuclear technology; nuclear industry; microreactors; hydrogen; energy cogeneration; combined heat and power

\section{Introduction}

We will increase the readiness of our forces and improve our ability to reinforce each other within Europe and across the Atlantic [1].

The strategic objectives of the North Atlantic Treaty Organisation (NATO, hereafter: the Alliance) include increasing the resilience of energy security by strengthening existing 
infrastructure, using it more efficiently, and acquiring alternative energy sources [2]. These objectives relate to the Alliance's activities before, during and after a crisis, including its participation in providing collective security beyond the borders of the organisation's member states [3]. These demonstrations of NATO's commitment imply the development of operational, stationary and mobile capabilities that enhance the resilience of member states and their armed forces [4]. A reliable and efficient energy supply is essential for mission success and for guaranteeing the safety of soldiers. This involves the proper selection of tools (both military and non-military) and procedures for their use, which will result in much greater efficiency and effectiveness compared to current, traditional methods of ensuring energy security [5].

In this paper we introduce a previously unpresented approach to fuel production for NATO operations, suggesting the possibility of using mobile high-temperature nuclear reactors (HTR) to produce hydrogen $\left(\mathrm{H}_{2}\right)$ as fuel. The use of nuclear-hydrogen synergy will make it possible to dispense with the supply of fossil fuels for North Atlantic Alliance operations, as the needed fuel will be produced locally, during the mission. The search for new, alternative fuel sources is particularly important at a time of transition away from fossil fuels and uncertainty about the continuity of their supply.

The purpose of this article is to identify a model of nuclear-hydrogen synergy for use during NATO operations. We have identified opportunities and threats for mobile power generation using nuclear-hydrogen synergy in NATO operations. Our research indicates the best method for hydrogen production by electrolysis using a nuclear microreactor. Electrolysis is an environmentally 'clean' solution and a popular choice due to the simplicity of the process. However, it is less efficient than chemical processes based, for example, on the iodine-sulphur cycle. In this paper, we present the results of a study that indicates which method and which cycle is most suitable for hydrogen production using minireactors in North Atlantic Treaty Organisation operations. Verification criteria include process efficiency, complexity and residues generated by the process (waste) in the context of military applications.

\section{Analysis of NATO's Energy Needs}

Evolutions in equipment and the use of technological innovations in the military have contributed to the increased mission criticality of fuel supply. The energy intensity of warfighting increased 16 -fold and the oil intensity of a single soldier increased by $2.6 \%$ per year between 1970 and 2010 [6]. During World War II, the United States used about 5 litres of fuel per soldier per day, whereas during the 1990-91 Gulf War, it used about 15 litres of fuel per soldier per day. In 2006, during operations in Iraq and Afghanistan, the U.S. burned an average of about 60 litres of fuel per soldier per day [6]. The modern battlefield requires about 75 litres of fuel per soldier per day. High-tech combat equipment weighs up to $40 \mathrm{~kg}$, of which batteries alone take up to $20 \%$ of the total weight. This affects the mobility of soldiers and their tactical advantage (Figure 1) [7]. Furthermore, it implicates access to the refuelling capabilities during the logistics of NATO's operations.

The latest report on operational energy published by US Department of Defence shows that annual energy demand fluctuates between 80 and 100 million barrels (2013-2019) [9]. Most fuel was purchased close to the point of use in order to deliver it as quickly as possible and reduce the risks associated with transportation [9]. The most energy-intensive is the air force, followed by the navy (Figure 2). 


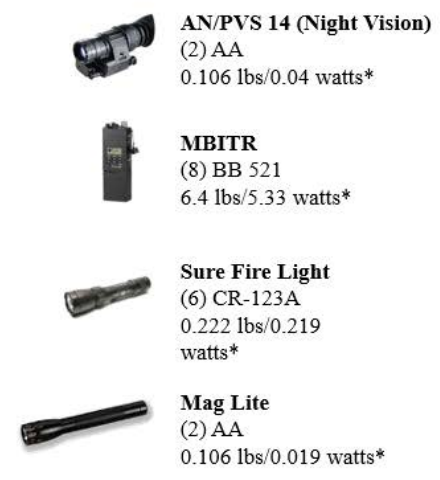

AN/PVS 14 (Night Vision)

(2) AA

MBITR

(8) BB 52

watts*

$0.106 \mathrm{lbs} / 0.019$ watts*
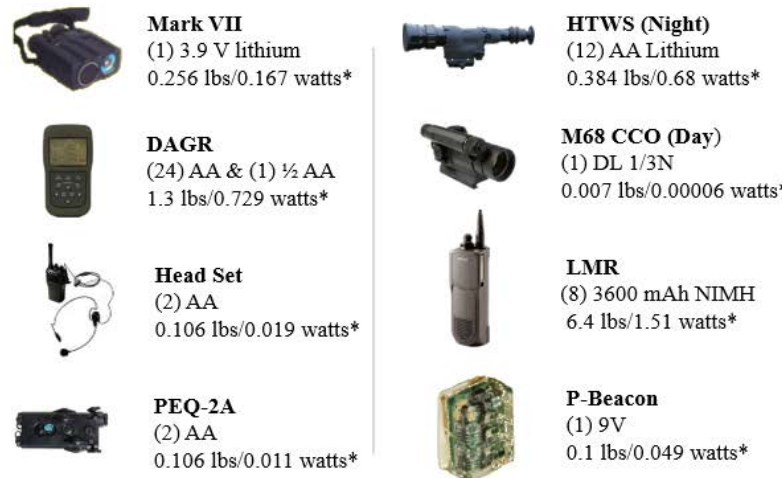

Total: 7 types of batteries,

70 batteries, $8 \mathrm{~kg}$; 9.16 watts

Figure 1. Average equipment of a soldier. Source: [8].

\begin{tabular}{|c|c|c|c|c|c|c|c|c|c|c|}
\hline & & FY13 & FY14 & FY15 & FY16 & FY17 & FY18 & FY 19 & FY20e & FY21e \\
\hline \multirow{6}{*}{ 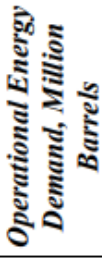 } & Army & 12.7 & 10.1 & 7.3 & 7.1 & 7.6 & 9.2 & 9.0 & 9.3 & 9.4 \\
\hline & Navy & 28.4 & 28.2 & 28.5 & 28.5 & 28.4 & 26.0 & 28.1 & 24.5 & 24.5 \\
\hline & Air Force & 47.8 & 48.6 & 52.0 & 49.6 & 49 & 51.9 & 45.3 & 51.2 & 50.6 \\
\hline & Marine Corps & 0.2 & 0.2 & 0.2 & 0.2 & 0.2 & 0.5 & .38 & .5 & .5 \\
\hline & Other DoD & 0.7 & 0.3 & 0.5 & 0.4 & 0.3 & 0.9 & .77 & 2.1 & 2.1 \\
\hline & Demand & 89.8 & 87.4 & 88.6 & 85.7 & 85.5 & 88.5 & 83.6 & 87.6 & 87.1 \\
\hline & $\frac{\text { Expenditures }}{\text { (Billions) }}$ & $\$ 14.8$ & $\$ 14.0$ & $\$ 14.1$ & $\$ 8.7$ & $\$ 8.2$ & $\$ 9.1$ & $\$ 11.0$ & $\$ 10.9$ & $\$ 10.9$ \\
\hline
\end{tabular}

Figure 2. DoD operational energy demand by service, source: [9].

NATO's energy consumption is created by two types of needs: energy for fixed installations and operational energy in the field. Military installations house critical systems that must operate continually $24 \mathrm{~h}$ a day. Therefore, the ability to access and supply reliable sources of energy to meet needs in both dimensions is critical.

Operational energy costs are significantly higher than those of fixed military installations due to the unpredictability of combat operations and fuel consumption levels, combined with the logistical costs of transporting and protecting fuel convoys. Additionally, the army's energy needs are constantly increasing, not only due to technological development of equipment, but also because NATO's national military bases have expanded their role from training troops to supporting frontline operations, crisis response and humanitarian assistance [7]. NATO ENSEC COE defines operational energy security in terms of

uninterrupted access to reliable supplies of energy resources, capability to employ alternative energy sources in an operational environment, efficient and environmentally friendly use of energy resources and the ability to protect and safely deliver sufficient energy resources to meet operational needs without limiting combat capability [8].

Forward Operating Bases (FOBs) play a key role in supporting expeditionary and campaign capabilities of NATO's operations because they must be able to provide basic services. Fuel and energy shortages can disable operations and disrupt critical support functions. At the same time, the transportation of fuel alone represents the lion's share of FOB energy costs. Fuel convoys are susceptible to theft, damage from improvised explosive devices, insurgent attacks, or the enemy's regular and irregular actions. Estimates from operations in Afghanistan show that there is one fatality for every 46 convoys. In 2007, one American soldier or contractor was wounded or killed for every 24 fuel convoys. NATO supplied about half of the fuel consumed by international forces in Afghanistan. Fuel consumption increased from 23 million litres per year in 2004 to 1 billion litres per year 
in 2010. At the peak of the operation, there were some 5396 trucks supplying US forces daily in Afghanistan, as well as ca. 1306 energy fuel trucks of NATO and Defence Logistics Agency [7].

Regardless of technological improvements, the military's need for fuel may experience spikes. Such a surge in jet fuel purchases occurred in 1999 in the wake of NATO's 78-day air war in Kosovo, in which the U.S. committed more than 500 aircraft. The 78-day NATO air war in Kosovo (1999) reflects well the unpredictability of combat operations [10]. Another example is Operation Iraqi Freedom (2003), when the coalition air forces numbered 1801 aircraft, 863 of which were U.S. Air Force. In the first six weeks, coalition air forces flew more than 41,000 sorties. The Air Force tankers disbursed more than 376 million pounds of fuel [11]. For comparison, it is worth citing figures for peacekeeping missions, sixteen of which are overseen by the United Nations. In the budget period 2015/16, fuel was provided for 32,600 vehicles, 239 aircraft, 8670 generators and other fuel-consuming equipment, with a consumption of approximately 340 million litres [12].

From the above facts, we can conclude that sourcing fuel locally can save a lot of money. For example, flying 120,000 litres of fuel to Afghanistan costs $\$ 300,000$. It is therefore preferable to buy fuel locally [13]. The integration of nuclear-hydrogen synergy energy production into operational theatres would enable Allies' militaries to generate their own energy on-site. This would decrease the demand for fossil fuel at FOBs and lessen the need for costly and dangerous fuel convoys [7].

NATO forces are heavily dependent on fossil fuels, resulting in high monetary costs, security risks and casualties [7]. For these reasons, there is a shift in NATO towards military capabilities powered by electricity instead of those powered by fossil fuels. NATO has been exploring alternatives to fossil fuels for some time now, as demonstrated by declarations at recent summits in Chicago (2012), the Wales Summit (2014) and the Warsaw Summit (2016), among others. A key role is played by the Green Defence Framework approved in February 2014, which sets out three priority pillars: operational effectiveness, environmental protection, and energy efficiency. In line with this, NATO aims to meet logistical challenges, reduce risks for soldiers protecting fuel convoys and reduce NATO's environmental footprint [14]. Furthermore, it should also be able to take responsibility for purely civilian directed actions supporting societies on different continents [15].

\section{The Potential of Mobile Micro-Reactor Technologies}

Military needs include the acquisition of processed energy in the combat zone, the use of which is unlimited in time and space. The only constraints stem from the possibilities of energy transmission [16]. The current concept of nuclear microreactors assumes that they can be used in a variety of ways. This is due to the optimisation of reactor size and mass, which allows them to be transported freely and to apply the plug-and-play principle. The result is the generation of electricity at the level of a few or tens of megawatts. Such technological progress is linked to the introduction of radiation safety regulations, which guarantee the safe operation of the reactor under all conditions of transport and stationary use.

The use of high-temperature reactors allows the application of nuclear-hydrogen synergy for hydrogen production [17]. Coupling nuclear energy with hydrogen production enables two synergistically linked processes: thermochemical and electrochemical. Using them to produce process heat, as well as nuclear electricity, is a zero-emission solution with no greenhouse gas emissions.

Furthermore, the combination of nuclear micro-reactor [18] and hydrogen technologies offers the possibility of local production of carbon-free fuel with high energy density. Hydrogen offers great military potential as a fuel source, but also plays an important role in the chemical, fertiliser, petrochemical and food industries. Hydrogen may be the key to the success of mobile nuclear power plants [19] because not only is it a high-energy gas, but also the electrochemical and thermochemical processes do not emit carbon dioxide, unlike the chemical processes of making hydrogen from natural gas. 
The high-temperature mobile nuclear reactors operating in the United States have a core temperature of $1000{ }^{\circ} \mathrm{C}$. This allows for cogeneration, i.e., the simultaneous generation of electricity and heat without emitting carbon dioxide. Furthermore, by using hydrogen as a source of process heat in the 700 to $950{ }^{\circ} \mathrm{C}$ output temperature range, HTR reactors can be an important part of nuclear-hydrogen synergy. Their technological advantage over other comparable solutions lies primarily in the possibility of further miniaturisation and weight reduction.

Research on micro reactors is being conducted by the US Department of Defense as part of work being undertaken in two projects: eVinci and PELE. These are not the first projects undertaken to develop mobile nuclear energy sources [20].

\subsection{Project eVinci}

The eVinci project is being carried out by Westinghouse in collaboration with US companies and national laboratories that play an important role in the development of nuclear technology, including Los Alamos National Laboratory (LANL) [21]. The project has developed a high-temperature, ducted nuclear reactor. The reactor is very small, mobile and consists of the latest generation of modules. Its purpose is to provide cogeneration of process heat and electricity with a capacity of 1 to $5 \mathrm{MW}$. The design is based on a compact monolithic unit with three types of channels containing fuel, moderator and coolant. The developers of the reactor intend to design and license it by 2022, so that the project can be commercialised around 2025 [22].

The eVinci reactor is fully separated from the external environment by a series of protective barriers that ensure radiological safety even if the reactor is abandoned [23]. The first barrier is the encapsulation of the TRISO fuel. The second barrier is a monolithic block with no moving mechanical parts. The reactor core is surrounded by a neutron reflector and, in addition, a shield to protect against gamma radiation. All this is enclosed in a steel cylinder, which is the final protective layer. The reactor was designed as a sub-critical one. It requires an efficient moderator-neutron reflector system to work. If either of these fails, the reactor will shut down automatically (Figure 3).

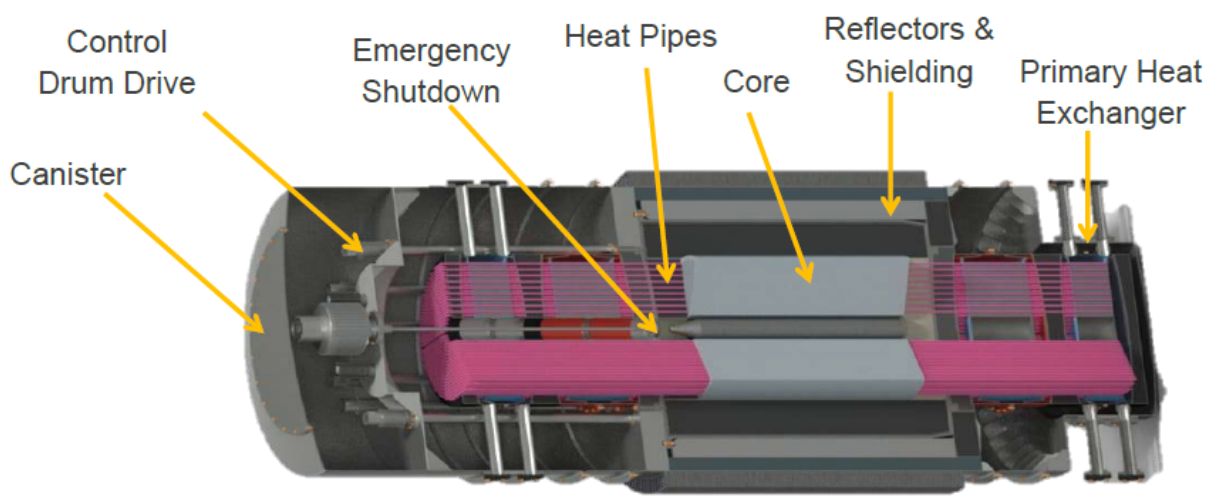

Figure 3. eVinci micro-reactor cutaway. Source: [6].

Westinghouse's design priority is to deliver a design capable of easy transportation, minimal maintenance needs, instant start-up, and operating anywhere without interruption for three or more years. The reactor is intended to serve energy consumers in remote, offgrid locations (military bases, residential buildings, industrial and military infrastructure). The eVinci nuclear microreactor is envisaged to ensure transportability by trailer, rail and sea. Its design enables:

- mounting in standard transport containers;

- $\quad$ an assembly, filling, and preparation for operation in production facilities;

- $\quad$ start-up in an on-site installation in less than 30 days;

- a cogeneration of process heat and power at a level of 1-5 MWe; 
- a minimum service life of 40 years;

- at least three years of operation between refuelling;

- an autonomous operation, high reliability, and minimal moving parts;

- a near-zero containment zone (in terms of nuclear safety) which guarantees the land rehabilitation into so-called "green grass" immediately after the reactor is removed from the site.

\subsection{Project PELE}

Another type of solution currently being tested is the microreactor developed under the PELE project by the US Department of Defence. As with the eVinci project, the PELE project adopted solutions to create a nuclear microreactor that could be used at remote operational bases of the US Armed Forces. Project participants are tasked with developing a prototype mobile high-temperature gas-cooled microreactor (HTGR). The reactor should have a generating capacity of 1-5 MW and berefuelled no more than once every three years. It must also meet the requirements of mobility, that is, the microreactor must be easily transported (both before and after operation) by truck, train, or plane. All essential reactor components must fit into a standard 40-foot-long container [24].

The high-temperature reactors (operating at temperatures exceeding $2000{ }^{\circ} \mathrm{C}$ ) [25], which are being developed within the eVinci and PELE projects, have two important advantages over water-cooled reactors. The first is that the core is protected by TRISO capsules enriched to $=<19.8 \%$, which contain the nuclear fuel [24]. The intention behind the use of this type of fuel is to guarantee radiological safety in the event of attack nd destruction of the reactor. The capsules are to ensure that there is no fuel leakage even if the reactor containment is damaged. A second advantage is that, unlike water-cooled reactors, high-temperature reactors are not prone to destruction of structural elements and melting of the fuel rods when the core temperature reaches about $1300{ }^{\circ} \mathrm{C}$ [25].

\section{Nuclear-Based Hydrogen Production}

Hydrogen used as a fuel can be used in many ways: burned as a stand-alone fuel, used in fuel cells, or as a feedstock for the synthesis of other fuels. Hydrogen is not only important for powering motor vehicles, but can also be used in a range of industries:

- the petrochemical industry, in hydrocracking processes;

- the fertiliser industry—in the production of ammonia;

- carbon-nuclear synergy-for the production of synthetic fuels.

If we consider the global production of this compound, we find that:

- $48 \%$ of total $\mathrm{H}_{2}$ production is generated by steam decomposition of methane;

- $30 \%$ of total $\mathrm{H}_{2}$ production comes from crude oil processing at refineries;

- $18 \%$ of total $\mathrm{H}_{2}$ production comes from coal gasification processes;

- $4 \%$ of total $\mathrm{H}_{2}$ production is from water electrolysis.

The above shows that almost half of the hydrogen is produced by an environmentally unfriendly method as the result of a series of reactions represented by the following formula [26]:

$$
\mathrm{CH}_{4}+2 \mathrm{H}_{2} \mathrm{O} \rightarrow \mathrm{CO}_{2}+4 \mathrm{H}_{2}
$$

This means that for every tonne of hydrogen produced, 5.5 tonnes of carbon dioxide are released into the atmosphere. The other listed methods of producing hydrogen are not flawless either. Refinery gas-phase steam conversion also emits significant amounts of carbon dioxide. Besides emitting greenhouse gases, both of these methods and coal gasification also require access to raw materials that are naturally available only in limited geographical areas. One of the easiest methods of producing hydrogen is water electrolysis, which is the process of breaking down a water molecule into hydrogen and oxygen using an electric current. Acid or alkaline water solutions, or alcohol mixtures are used for water electrolysis to optimise the efficiency of this process.

The electrolysis of water occurs according to the following reactions: 
- $\quad$ cathodic reaction (reduction)

$$
2 \mathrm{H}_{2} \mathrm{O}+2 \mathrm{e}^{-} \rightarrow \mathrm{H}_{2}+2 \mathrm{OH}^{-}
$$

- $\quad$ anodic reaction (oxidation)

$$
2 \mathrm{H}_{2} \mathrm{O} \rightarrow \mathrm{O}_{2}+4 \mathrm{H}^{+}+4 \mathrm{e}^{-}
$$

In summary, the water electrolysis reaction is as follows:

$$
2 \mathrm{H}_{2} \mathrm{O} \rightarrow 2 \mathrm{H}_{2}+\mathrm{O}_{2}
$$

A high temperature reactor can be used as a source of process heat for hydrogen production. Indirect hydrogen production from water is one of the most promising hightemperature processes that could be used on a mass scale [27]. This process occurs in the sulfur-iodine (S-I) cycle according to the following scheme (Figure 4):

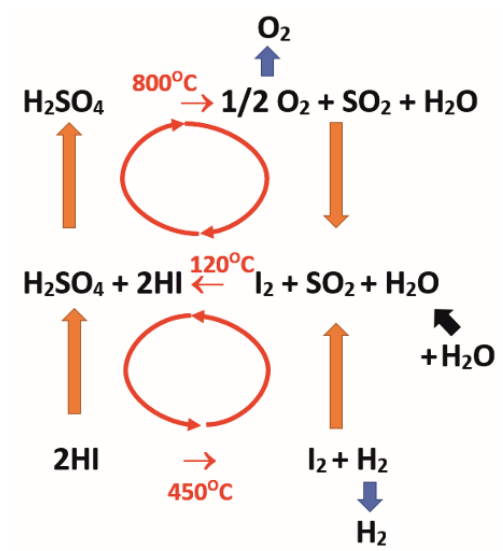

Figure 4. Diagram of the sulphur-iodine cycle (S-I). Source: Author's own research.

In this cycle, in a series of thermochemical reactions, hydrogen is produced by the breakdown of water. In this process, as in electrolysis, oxygen $\mathrm{O}_{2}$ is released as a by-product. The oxygen thus obtained can be separated and used in other processes.

\section{Application of Nuclear-Hydrogen Synergy in NATO Operations}

The effectiveness of Allied forces in peace, crisis or in conflict depends on the ability of the forces provided to operate together coherently, effectively and efficiently [28].

Joint allied operations should be prepared, planned and conducted in a manner that best utilises the strengths and capabilities of the forces offered by member states for peace, crisis and war operations. Technology is a fundamental dimension that determines the interoperability of the formations and units of the Alliance's multinational forces. In this respect, standardisation agreements (STANAG) play a special role, enabling the adoption of the same solutions both within and outside the Organisation with partner states [28].

Forecasting the impact of the next technological revolution with the spread of $5 \mathrm{G}$ technology as well as the implications of autonomous devices and the Internet of Things, we anticipate that the forms of NATO's energy acquisition, conversion and utilisation needs will be transformed. The use of the HTR as a mobile energy source offers the possibility to efficiently supply the North Atlantic Alliance's operations with three independent sources of energy, i.e., heat, electricity and hydrogen (as fuel). This presents an opportunity to procure different forms of energy depending on the actual demand.

When considering hydrogen harvesting with portable HTRs deployed in North Atlantic Treaty Organization operations, it is important to point out the ways in which it can be used. Firstly, hydrogen is a self-contained fuel used in fuel cells. It is also a substrate for the synthesis of other fuels. Secondly, hydrogen is not only important for powering 
vehicles, but can be used for other applications, such as 3D printing. Thirdly, hydrogen can be freely configured in the energy value chain: generation, storage and distribution, to provide energy for infrastructure used in or for certain operations.

The coordinated use of different types of energy generated by nuclear-hydrogen synthesis in North Atlantic Treaty Organization operations could ultimately enable power supply for:

1. Infrastructure (fixed and mobile) using wired and wireless forms of connectivity. The design of such power supply depends on the solutions implemented as part of the Internet of Things, using machines and devices that perform their tasks in a diverse environment (land, air, water, and even space in the long term);

2. Mobile fabrication and reproduction of machine or equipment components using 3D printers in metallurgical or manufacturing processes that involve materials other than metals, organised through mobile workshops and logistics bases. This provides an opportunity to further expand the existing range of operations carried out by NATO in diverse climatic as well as logistical conditions;

3. Universal forms of propulsion adapted to the needs of NATO operations (land, air, water, as well as in the future placing vehicles and equipment temporarily on the Earth orbit).

The implementation of the solutions described above will allow the use of military and non-military forms of energy generation, transmission and utilisation.

In our opinion, the future physical and psychological results of NATO-led operations using nuclear-hydrogen fusion deserve attention. It concerns the creation of advantages, the improvement of operational capabilities of troops, the strengthening of the resilience of individual states and the whole Alliance on its territory and beyond. The psychological factor of NATO's support for individual societies and states is of great importance. It manifests itself in the ways in which operations are conducted and is one of the sources of advantage determining the success of the operations undertaken. Situational awareness is also of great importance as it involves the certainty of a continuous power supply regardless of the forms of energy demand within the operation.

The use of nuclear-hydrogen synergy as an enabler of the organisation's operations reinforces the concepts of both deterrence and collective defence. This applies to the entire territory and population, the readiness of NATO forces to operate and perform their tasks in Europe and across the Atlantic. However, this requires an appropriate mix of conventional and missile defence capabilities, cyber defence and adaptation of procedures in the NATO Command Structure. There are opportunities to apply nuclear-hydrogen synergy at every level, i.e., military-strategic, operational and tactical. Particularly important in this respect is the readiness to meet hybrid threats for mobile infrastructure using nuclear-hydrogen synergy [29]. All these elements should be analysed and included in the framework of an energy security doctrine for the North Atlantic Alliance that uses mobile nuclear-hydrogen synergy sets for power generation.

Potential NATO adversaries may use energy aspects in their foreign policy, e.g., as tools in hybrid activities [30]. The use of nuclear-hydrogen synthesis in NATO operations could allow potential threats to be countered by:

- ensuring a stable and reliable energy supply to designated customers within and outside the alliance area;

- diversification of ways of acquiring, distributing, and supplying energy to various types of infrastructure;

- connectivity to resilient local energy networks.

The result of the approach outlined above will be greater operational flexibility for the North Atlantic Treaty Organization. The prerequisite for this, however, is strengthening NATO's resilience in cyberspace to ensure that allied forces have access at all times to energy resources as well as energy generation, distribution and ultimately energy use for ongoing operations. 


\section{Discussion}

The extraction of heat, electricity and hydrogen from mobile nuclear reactors is essential to the operations of the North Atlantic Treaty Organization. Energy efficiency and effectiveness are fundamental to mobile nuclear technology. This also applies to all of the mentioned forms of energy.

In the production of hydrogen by electrolytic methods, the initial stage is important in order to assess the benefits obtained in the thermal energy-hydrogen relationship. The efficiency of the electrolysis process is calculated as the production efficiency in proportion to the electrical energy supplied. The same applies to high-temperature electrolysis, in respect of the electrical and thermal energy supplied.

The Solid Oxide Electrolysis Cell method is considered to be the most efficient method of electrolytic hydrogen production. Under the most optimal conditions, the efficiency of hydrogen production exceeds $90 \%$. However, given the need to supply heat in the process, the actual efficiency (electrical + thermal) exceeds 75\% [31]. This level of efficiency in the electricity generation process appears to be the most technologically desirable. Nonetheless, this efficiency is calculated for the supplied electricity and in this case does not consider the cost of of its generation. Electricity in this case is primarily generated by converting heat energy.

In conventional power plants, heat converts the propellant from liquid to gas, which is then directed to turbines that convert the resulting mechanical energy into electricity. When considering the efficiency of hydrogen production, we must realise that different values are obtained depending on the method adopted. In making a solid analysis, we should adopt the same assumptions for each case under consideration. Therefore, the efficiency of hydrogen production by electrolytic methods, where electricity is needed, should not be directly compared with thermochemical methods based on heat energy. Electricity does not arise on its own; it has to be generated. The generation of this energy is also subject to a certain degree of efficiency, which directly affects the assessment of the efficiency of the entire hydrogen production process.

While conventional nuclear power plants achieve efficiencies of the order of 30-33\%, coal-fired plants achieve efficiencies of up to $45-48 \%$, as do HTR reactors. By comparison, the most advanced gas-fired power plants in operation today achieve efficiencies in excess of $55 \%$ [32].

In the thermochemical process of hydrogen production, and in particular in the process based on the sulfur-iodine method, this efficiency is 78\% [33]. We must emphasise that the efficiency value is inversely proportional to the energy supplied to the process, which depends on the sum of heat flows. In order to comprehensively determine the nature of hydrogen production processes, we must refer to efficiencies determined not by heat flows but by mass. In this case, the actual efficiency is $71 \%$ [34]. This is despite the fact that hydrogen production by thermochemical methods is more efficient.

\section{Conclusions}

In line with technological developments, the increasing functionality of hydrogen is undeniable and has also been recognised by NATO. Hydrogen has a much higher energy density per unit mass than other fuels [35], which means that hydrogen fuel can increase the range of military vehicles. Consequently, hydrogen could eliminate the need for risky refuelling stops during missions, as well as the number of fatalities associated with fuel delivery in combat areas. Its use would increase the operational capabilities of the Alliance's troops and also help with energy storage.

Our research analysis in this article shows that mobile hydrogen-based technologies combined with the use of nuclear microreactors are a promising prospect. Nuclear microreactors are small enough to be easily transported to their destination by heavy trucks. Depending on their design, nuclear microreactors are capable of generating 1-20 MW of thermal energythat can be used directly as heat or converted to electricity or for nonelectrical applications such as hydrogen fuel production. 
Although thermochemical methods are characterised by greater efficiency, especially when using nuclear-hydrogen synergy, they can potentially be used only in industrial conditions due to the need for highly corrosive substances and the potential to generate environmentally harmful chemical waste. Therefore, we recommend that mobile solutions for the military not use these technologies.

While thermochemical methods have higher efficiencies, especially when using nuclear-hydrogen synergy, they can potentially only be used in industrial settings due to the need for highly corrosive substances and the potential to generate environmentally harmful chemical waste. Therefore, we recommend that mobile solutions not use these technologies.

The electrolytic methods for hydrogen generation combined with nuclear microreactors appears to be the best for implementation in mobile applications. However, they are less efficient than thermochemical methods. On the other hand, electrolytic methods are easier to implement and simpler to operate. They generate less potentially hazardous waste and are safer to use. Simplicity of design is also a significant advantage (Table 1).

Table 1. Comparison of hydrogen production with electrolytic and thermochemical methods* in mobile use.

\begin{tabular}{|c|c|c|c|c|c|c|c|}
\hline 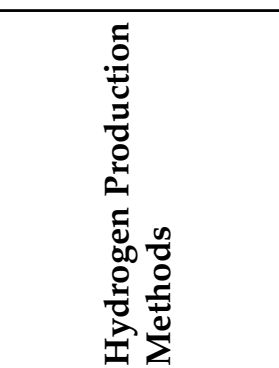 & 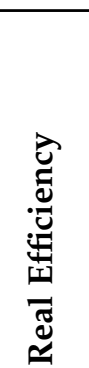 & 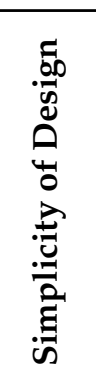 & 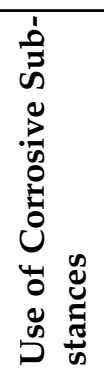 & 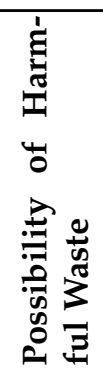 & 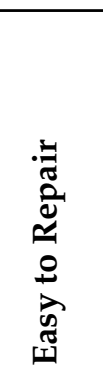 & 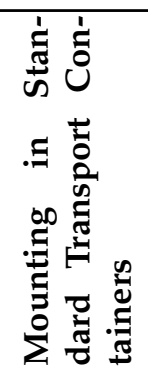 & 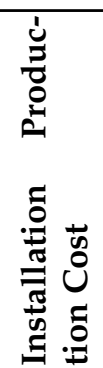 \\
\hline $\begin{array}{c}\text { Electrolytic } \\
\text { Thermochemical }\end{array}$ & $\begin{array}{l}36 \% \\
71 \%\end{array}$ & $\begin{array}{l}\text { Low } \\
\text { High }\end{array}$ & $\begin{array}{l}\text { No } \\
\text { Yes }\end{array}$ & $\begin{array}{l}\text { None } \\
\text { Small }\end{array}$ & $\begin{array}{l}\text { High } \\
\text { Low }\end{array}$ & $\begin{array}{c}\text { Easy } \\
\text { Possible }\end{array}$ & $\begin{array}{l}\text { Low } \\
\text { High }\end{array}$ \\
\hline
\end{tabular}

Source: Author's own research. The efficiency value of the electrolytic method is calculated by the combination of the efficiency of electricity production in an HTR reactor and the efficiency of hydrogen production by the electrolytic method.

Given the North Atlantic Treaty Organization's commitment to environmental protection, this form of energy generation and use of hydrogen should be considered as being of interest but not of potential use. For the specified mobile energy, heat and hydrogen extraction methods, preference should be given to electrolytic or high temperature electrolytic methods. This is because water electrolysis is a simpler process and therefore easier to use in field conditions. Moreover, it is environmentally friendly and does not leave a significant carbon footprint.

Given the North Atlantic Treaty Organization's commitment to environmental protection, this form of energy generation and hydrogen use should be considered interesting, but not necessarily useful. For specified methods of mobile energy, heat and hydrogen generation, preference should be given to electrolytic or high temperature electrolytic methods. This is because water electrolysis is a simpler process and therefore easier to apply in field conditions. Moreover, it is environmentally friendly and does not leave a significant carbon footprint.

Considering the conclusions of the analysis of opportunities and risks associated with the use of hydrogen, we can see that hydrogen can be used in particular as a fuel source for transport. Its properties confirm that hydrogen as a fuel will find application mainly in the area of heavy transport, which is specific to the armed forces. At the same time, bearing in mind NATO's energy and climate priorities, there is no doubt that hydrogen represents an opportunity for the modernization of the Alliance's armed forces. Given the current early stage of hydrogen technology deployment, consideration should be given to introducing solutions across the whole of the North Atlantic Treaty Organization and partner states 
that would standardize the use, distribution, and operation of hydrogen according to the needs of the Organization.

Author Contributions: Hereby we declare the following author contributions: conceptualization, J.G., K.K., A.W. and M.R.; methodology, K.K.; validation, K.K.; formal analysis, J.G., K.K., A.W. and M.R.; investigation, J.G., K.K., A.W. and M.R.; resources, J.G., K.K., A.W. and M.R.; data curation, K.K.; writing - original draft preparation, J.G., K.K., A.W. and M.R.; writing—review and editing, J.G., A.W. and M.R.; supervision, J.G. All authors have read and agreed to the published version of the manuscript.

Funding: This research received no external funding.

Institutional Review Board Statement: Not applicable.

Informed Consent Statement: Not applicable.

Data Availability Statement: Not applicable.

Conflicts of Interest: The authors declare no conflict of interest.

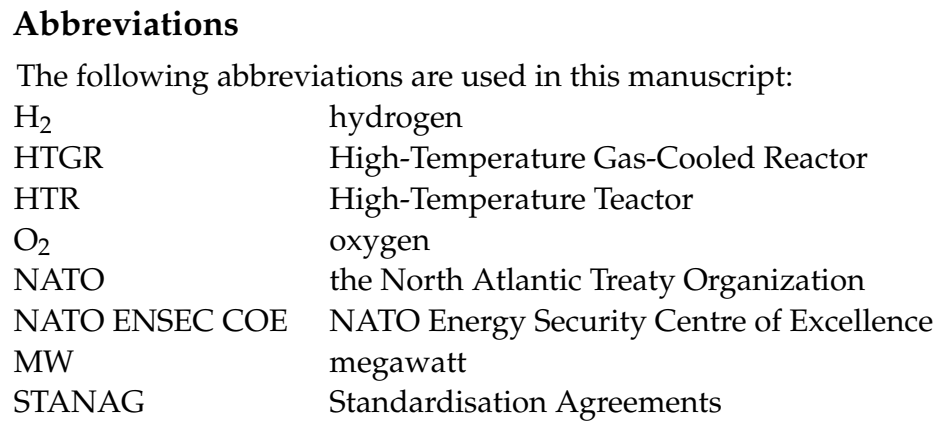

\section{References}

1. Brussels Declaration on Transatlantic Security and Solidarity. Issued on 11 July 2018. Available online: https:/ /www.nato.int/ $\mathrm{cps} /$ en/natohq/official_texts_156620.htm?mode=pressrelease (accessed on 28 May 2021).

2. Grubliauskas, J.; Rühle, M. Energy Security: A Critical Concern for Allies and Partners. NATO Review, 26 July 2018. Available online: https:/ /www.nato.int/docu/review/articles/2018/07/26/energy-security-a-critical-concern-for-allies-and-partners/ index.html (accessed on 28 May 2021).

3. NATO Strategic Concept. Active Engagement, Modern Defence, Strategic Concept for the Defence and Security of the Members of the North Atlantic Treaty Organization. In Proceedings of the Heads of State and Government at the NATO Summit in Lisbon, Lisbon, Portugal, 19-20 November 2010; pp. 7-8.

4. Ruszel, M. NATO and energy security in European Union. In A Transatlantic or European Perspective of World Affairs: NATO and the European Union Towards Problems of International Security in the 21st Century; Podraza, A., Ed.; Biblioteca Benjamin Franklin: Madrit, Spain, 2018; pp. 169-182.

5. Deni, J.R. Energy Self-Sufficient Military Installations: Rewards and Obstacles. Energy Secur. Oper. Highlights 2013, 2, 3.

6. Nuttall, W.J.; Samaras, C.; Bazilian, M. Energy and the Military: Convergence of Security, Economic, and Environmental Decision-Making. EPRG Working Paper 1717; Cambridge Working Paper in Economics 1752. 2019; pp. 9-10. Available online: https://www.eprg.group.cam.ac.uk/wp-content/uploads/2017/11/1717-Text.pdf (accessed on 28 May 2021).

7. Bitoun, J. Operational Green. Enhancing NATO's Energy Supply Security. Res. Pap. 2014, 106, 1-11.

8. Presentation on Energy Security by Romualdas Petkevičius, Director of NATO Energy Security Centre of Excellence. Available online: https://kam.lt/download/37201/nato\%20ensec\%20coe\%20presentation,\%20col\%20romualdas\%20petkevicius.pptx (accessed on 28 May 2021).

9. Fiscal Year 2019. Operational Energy Annual Report. Office of the Under Secretary of Defense for Acquisition and Sustainment. 2020; pp. 2, 18-19. Available online: https:/ /www.acq.osd.mil/eie/Downloads/OE/FY19\%20OE\%20Annual\%20Report.pdf (accessed on 28 May 2021).

10. 1999-Operation Allied Force. Air Force Historical Support Division. Available online: https://www.afhistory.af.mil/FAQs/ Fact-Sheets/Article/458957/operation-allied-force/ (accessed on 28 May 2021).

11. 2003-Operation Iraqi Freedom. Air Force Historical Support Division. Available online: https://www.afhistory.af.mil/FAQs/ Fact-Sheets/Article/458942/2003-operation-iraqi-freedom/ (accessed on 28 May 2021).

12. Electronic Fuel Management-Overview. United Nations-Support to Peacekeeping Operations. Available online: https: //lpk.ilearn.un.org/course/category / 1 (accessed on 28 May 2021). 
13. Ammitzboell, K. Unintended consequences of peace operations on the host economy from a people's perspective. In Unintended Consequences of Peacekeeping Operations; Aoi, C., de Coning, C., Thakur, R., Eds.; Publishing House, United Nations University Press: Tokyo, Japan, 2007; p. 84. Available online: https://collections.unu.edu/eserv/UNU:2483/pdf9789280811421.pdf (accessed on 28 May 2021).

14. Mayor-Hilsem, D.; Zimmermann, R. A Review of Fuel Cells and Their Military Applications. Energy Secur. Oper. Highlights 2019, $12,21$.

15. Halkos, G.E.; Gkampour, E.-C. Coping with Energy Poverty: Measurements, Drivers, Impacts, and Solutions. Energies 2021, 14, 2807. [CrossRef]

16. Gryz, J. The future of energy security of states. Secur. Def. Quart. 2020, 29, 24-31. [CrossRef]

17. Santos, A.L.; Cebola, M.-J.; Santos, D.M.F. Towards the Hydrogen Economy-A Review of the Parameters That Influence the Efficiency of Alkaline Water Electrolyzers. Energies 2021, 14, 3193. [CrossRef]

18. Small Modular Reactors: Nuclear Energy Market Potential for Near-Term Deployment; NEA No. 7213; Nuclear Energy Agency, Organisation For Economic Co-Operation and Development: Paris, France, 2016.

19. Rosenstie, A.; Monnerie, N.; Dersch, J.; Roeb, M.; Pitz-Paal, R.; Sattler, C. Electrochemical Hydrogen Production Powered by PV/CSP Hybrid Power Plants: A Modelling Approach for Cost Optimal System Design. Energies 2021, 14, 3437. [CrossRef]

20. Vitali, J.A.; Lamothe, J.G.; Toomey, C.J., Jr.; Peoples, V.O.; Mccabe, K.A. Study on the Use of Mobile Nuclear Power Plants for Ground Operations; Deputy Chief of State G-4, United States Army: Arlington, TX, USA 2018.

21. Arafat, Y.; Van Wyk, J. Westinghouse Electric Company LLC the eVinci ${ }^{\mathrm{TM}}$ Micro Reactor Nuclear Demonstration Unit Readiness Project; U.S. Department od Energy Office of Nuclear Energy: Washington, DC, USA, 2020.

22. Arafat, Y.; Van Wyk, J. eVinci Micro Reactor. Nuclear Plant J. 2019, 34.

23. Maioli, A.; Detar, H.; Haessler, R.; Friedman, B.; Belovesick, C.; Cobel, J.S.; Kinnas, S.; Smith, M.; van Wyk, J.; Fleming, K. Modernization of Technical Requirements for Licensing of Advanced Non-Light Water Reactors Westinghouse eVinciTM Micro-Reactor Licensing Modernization Project Demonstration; Document Number SC-29980-202; U.S. Department of Energy (DOE) Office of Nuclear Energy Under DOE Idaho Operations Office: Washington, WA, USA, 2019.

24. DOE-ID NEPA CX DETERMINATION. Idaho National Laboratory. November 2019. Available online: https://www.energy.gov/ sites/prod/files/2013/11/f5/CX-010768.pdf (accessed on 28 May 2021).

25. High Temperature Gas Cooled Reactor Fuels and Materials; IAEA: Vienna, Austria, 2010. Available online: https://www-pub.iaea. org/MTCD/Publications/PDF/TE_1645_CD/PDF/TECDOC_1645.pdf (accessed on 28 May 2021).

26. Kochański, M.; Korczak, K.; Dybiński, O.; Kwas, M.; Osipowicz, K.; Patejuk, A.; Sawicka, A.; Swoczyna, B. Techniczne i Ekonomiczne Perspektywy Produkcji i Magazynowania Wodoru w Polsce; Acta Innovations: Konstantynow Lodzki, Poland, $2013 ;$ p. 51.

27. Król, K. Niezależność energetyczna Polski w formule synergii węglowo-jądrowej. In Bezpieczeństwo Energetyczne-Koncepcje i Wyzwania; Gryz, J., Podraza, A., Ruszel, M., Eds.; PWN: Warszawa, Poland, 2018.

28. NATO Standard AJP-01 Allied Joint Doctrine; Edition E Version 1; NATO Standardization Office (NSO): Brussels, Belgium, 2017; p. 2.

29. Jakson, H.; Byrne, J.B.; Cecchetti, E.N.; Ciampor, J.; Hayek, J.; Hausler, M.; Dubrova, K. Hybrid Warfare against Critical Energy Infrastructures Study, Energy in Irregular Warfare; Energy Conflict Series. 2017; pp. 26-32. Available online: https: //www.enseccoe.org/data/public/uploads/2017/05/irregular_warfare_176x250mm_20170526.pdf (accessed on 28 May 2021).

30. NATO 2030. United for a New Era; Analysis and Recommendations of the Reflection Group Appointed by the NATO Secretary General. 25 November 2020; p. 39. Available online: https:/ /www.nato.int/nato_static_fl2014/assets/pdf/2020/12/pdf/201201 -Reflection-Group-Final-Report-Uni.pdf (accessed on 28 May 2021).

31. Ghezel-Ayagh, H.; Brown, C.; Jolly, S.; Pastula, M.; Tang, E.; Wood, T. Modular Solid Oxide Electrolysis Cell System for Efficient Hydrogen Production at High Current Density. Infrastructure and Systems RD/Technology Acceleration FY 2019 Annual Progress Report, DOE Hydrogen and Fuel Cells Program. Available online: https:/ / www.hydrogen.energy.gov/pdfs/progress1 9/ins_ta019_ghezel-ayagh_2019.pdf (accessed on 28 September 2021).

32. Suppes, G.J.; Storvick, T.S. Production of Electricity. In Sustainable World. Sustainable Nuclear Power; Academic Press: Cambridge, MA, USA, 2007.

33. Yildiz, B.; Kazimi, M.S. Efficiency of hydrogen production systems using alternative nuclear energy technologies. Int. J. Hydrog. Energy 2006, 31, 77-92. [CrossRef]

34. García, L.; González, D.; García, C.; García, L.; Brayner, C. Efficiency of the sulfure-iodine thermochemical water splitting process for hydrogen production based on ADS (accelerator driven system). Energy 2013, 57, 469-477. [CrossRef]

35. Pethaiah, S.S.; Sadasivuni, K.K.; Jayakumar, A.; Ponnamma, D.; Tiwary, C.S.; Sasikumar, G. Methanol Electrolysis for Hydrogen Production Using Polymer Electrolyte Membrane: A Mini-Review. Energies 2020, 13, 5879. [CrossRef] 